\title{
FAKTOR-FAKTOR DETERMINAN TINGKAT KESEJAHTERAAN RUMAHTANGGA PESERTAP ROGRAM DESA MANDIRI PANGAN DI PROVINSI RIAU
}

\author{
Lisbeth Pininta, Djaimi Bakce,Jum'atri Yusri \\ Jurusan Agribisnis, Fakultas Pertanian, Universitas Riau, Pekanbaru, Indonesia \\ Email: fretayordinialaura@gmail.com
}

\begin{abstract}
Abstrak
Pemerintah Indonesia telah melaksanakan berbagai program untuk meningkatkan kesejahteraan masyarakat di Provinsi Riau. Salah satunya adalah Program Desa Mandiri Pangan yang telah dilaksanakan sejak Tahun 2006. Penelitian ini bertujuan untuk mengetahui faktor-faktor determinan tingkat kesejahteraan rumahtangga peserta Program Desa Mandiri Pangan di Provinsi Riau.Metode analisis yang digunakan pada penelitian ini adalah analisis regresi multinomial logistik.Hasil analisis menyimpulkan bahwa faktor-faktor determinan yang mempengaruhi tingkat kesejahteraan rumahtangga peserta Program Desa Mandiri Pangan di Provinsi Riau adalah luas kepemilikan lahan, frekuensi pendampingan, umur kepala rumahtangga, tingkat pendidikan kepala rumahtangga, dan frekuensi pertemuan kelompok.
\end{abstract}

Kata Kunci: Kesejahteraan Rumahtangga, Program Desa Mandiri Pangan

\section{PENDAHULUAN}

Pemerintah Indonesia telah melakukan berbagai programuntuk meningkatkan kesejahteraan masyarakat. Programtersebut kemudian dievaluasi dan dikaji melalui suatu indikator apakah telah berhasil atau tidak untuk meningkatkan kesejahteraan masyarakat. Menurut Sunarti (2006) indikator keluarga sejahtera diperlukan sebagai suatu instrumen untuk mengukur pencapaian kinerja beberapa indikator dari program pemberdayaan keluarga.BKKBN (2004)menggunakan 23 (dua puluh tiga) indikator untuk menggolongkan keluarga ke dalam 5 (lima) katagori yakni Keluarga Pra Sejahtera, Keluarga Sejahtera I, Keluarga Sejahtera II, Keluarga Sejahtera III dan Keluarga Sejahtera III Plus. Keluarga miskin menurut BKKBN (2004) adalah keluarga yang tidak dapat memenuhi salah satu atau lebih dari enam indikator penentu kemiskinan alasan ekonomi yakni: (1) pada umumnya seluruh anggota keluarga makan dua kali sehari atau lebih; (2) anggota keluarga memiliki pakaian berbeda untuk dirumah, bekerja/sekolah dan bepergian; (3) bagian lantai yang terluas bukan dari tanah; (4) paling kurang sekali seminggu keluarga makan daging/ikan/telur; (5) setahun terakhir seluruh anggota keluarga

11 Faktor-Faktor Determinan Tingkat Kesejahteraan Rumahtangga Pesertap Rogram Desa Mandiri Pangan Di Provinsi Riau 
memperoleh paling kurang satu stel pakaian baru, dan (6) luas lantai rumah paling kurang delapan meter persegi untuk tiap penghuni.

Menurut Wijayanti dan Ihsannudin (2013),untuk meningkatkan kesejahteraan masyarakat diperlukan program dan strategi yang disesuaikan dengan kondisi dan faktor-faktor penyebabnya. Salah satu program pemerintah untuk meningkatkan kesejahteraan masyarakat dengan peningkatan pendapatan rumahtangga adalah Program Desa Mandiri Pangan.

Program Desa Mandiri Pangan ini bertujuan untuk meningkatkan kemampuan masyarakat desa dalam pengembangan usaha produktif berbasis sumber daya lokal, peningkatan ketersediaan pangan, peningkatan daya beli dan akses pangan rumah tangga, untuk dapat memenuhi kecukupan gizi rumah tangga, dan memanfaatkan sumberdaya alam secara efektif, efisien, dan berkelanjutan.Program Desa Mandiri Pangan merupakan kegiatan prioritas dalam rangka memberdayakan masyarakat miskin/rawan pangan agar mampu untuk mandiri, dalam rangka pencapaian sasaran program kegiatan ketahanan pangan.Pelaksanaan program dilakukan secara empat tahapan kegiatan yaitu: (1) tahap persiapan, (2) tahap penumbuhan, (3) tahap perkembangan dan (4) tahap kemandirian, dengan harapan adalah pada tahun ke 5,masyarakat tersebut akan menjadi masyarakat yang mandiri. Dengan mandirinya suatu masyarakat akan berdampak positif terhadap mobilitas tingkat kemiskinan atau kesejahteraan.Dalam pelaksanaannya Program Desa Mandiri Pangan menerapkan twin track strategy, yaitu: (1) membangun ekonomi berbasis pertanian dan perdesaan untuk menyediakan lapangan kerja dan pendapatan, dan (2) memenuhi kebutuhan pangan bagi kelompok masyarakat miskin di daerah rawan pangan melalui pemberdayaan dan pemberian bantuan langsung (BKP Kementerian Pertanian RI, 2010).

Menurut Zuchainah (2010) bahwa Program Desa Mandiri Pangan berhasil meningkatkan tingkat penghidupan dan kemajuan pola pikir masyarakat sasaran, namun program tersebut belum mampu untuk menurunkan angka kerawanan pangan secara efektif. Faktor-faktor yang dapat meningkatkan efektivitas pelaksanaan program adalah kapasitas dasar masyarakat dan partisipasi masyarakat.Selain itu, peranan stakeholder sangat menentukan kemajuan tingkat penghidupan dan pola pikir masyarakat.

12 Faktor-Faktor Determinan Tingkat Kesejahteraan Rumahtangga Pesertap Rogram Desa Mandiri Pangan Di Provinsi Riau 
Darwis (2014) juga melakukan kajian tentang Dampak Program Desa Mandiri Pangan terhadap Ketahanan Pangan dan Kemiskinan,yang telah dilaksanakan sejak tahun 2006 pada desa yang sudah masuk tahap kemandirian.Pemberdayaan rumahtangga miskin berdampak sangat positif terhadap kepercayaan diri, aspek gender dan kewirausahaan.Selanjutnya berkontribusi positif juga terhadap pemanfaatan kapital dalam adopsi teknologi pengembangan usaha produktif untuk meningkatkan kesejahteraan rumahtangga.

Untuk mengetahui keberhasilan pelaksanaan Program Desa Mandiri Pangan di Provinsi Riau, maka pada Tahun 2015 pemerintah melalui Badan Ketahanan Pangan Provinsi Riau melakukan kajian evaluasi dari dampak Program Desa Mandiri Pangan terhadap rumahtangga miskin. Dari kajian tersebut teridentifikasi adanya faktor-faktor determinan yang mempengaruhi peningkatan tingkat kesejahteraan rumahtangga peserta program. Maka tujuan dari penelitian ini adalah untuk mengetahui faktor-faktor determinan yang mempengaruhi peningkatan tingkat kesejahteraan rumahtangga peserta Program Desa Mandiri Pangan di Provinsi Riau.

\section{METODOLOGI PENELITIAN}

Penelitian ini dilakukan di Provinsi Riau, mencakup 7 (tujuh) Kabupaten/Kota yaitu Kabupaten Kampar, Kota Dumai, Kabupaten Rokan Hulu, Kabupaten Pelalawan, Kabupaten Rokan Hilir, Kota Pekanbaru, dan Kabupaten Siak, dengan jumlah responden sebanyak 225 orang.Jenis data yang digunakan adalah data sekunder. Data sekunder utama yang digunakan adalah datahasil kajian evaluasi dampak Program Desa Mandiri Pangan di Provinsi Riaupada Tahun 2015 yang merupakan kerjasama Badan Ketahanan Pangan Provinsi Riau dengan Lembaga Penelitian Pengabdian Masyarakat Universitas Riau (LPPM-UR). Disamping itu juga digunakan data-data yang bersumber dari dinas dan instansi terkait.

Menurut Retherford dan Choe (1992), model analisismultinomial logistik adalah model dimana variabel terikatnya berupa data katagorik yang terdiri dari tiga atau lebih kategori.Sedangkan variabel bebasnya merupakan data kontiniu maupun katagorik. Menurut Maddala (1992) setelah dilakukan pengestimasian parameter dengan menggunakan analisismultinomial logistik, juga dapat dilakukan perhitungan dampak perubahan variabel bebas terhadap peluang variabel terikat. 
Analisis dilakukan pada dimensi waktu antara kondisi awal program dengan kondisi Tahun 2015 untuk mengetahui hubungan fungsional Y sebagai variabel terikat dalam bentuk katagorik dengan variabel $\mathrm{X}$ sebagai variabel bebas. $\mathrm{Y}$ merupakan peluang tingkat kesejahteraan tertentu, sedangkan $\mathrm{X}$ sebagai variabel bebas adalah karakteristik rumahtangga, tingkat partisipasi rumahtangga, kepemilikan aset dan pendampingan. Karakteristik rumahtangga dengan proksi umur kepala rumahtangga, pendidikan kepala rumahtangga, jenis kelamin kepala rumahtangga dan jumlah anggota rumahtangga. Tingkat partisipasi rumahtangga dengan proksi besarnya pembayaran iuran kelompok, frekuensi pertemuan kelompok dan frekuensi mengikuti pelatihan. Kepemilikan aset dengan proksi luas kepemilikan lahan, sedangkan pendampingan dengan proksi intensif atau tidak dalam mengikuti pendampingan.

Merujuk pada Retherford dan Choe (1992), Maddala (1992), dan Hosmer (2013), untuk mengetahui faktor-faktor determinan tingkat kesejahteraanrumahtangga peserta Program Desa Mandiri Pangan dengan persamaan regresi logistik sebagai berikut :

$L i=\operatorname{Ln}\left[\frac{P i}{1-P i}\right]=Z i$.

Berdasarkan persamaan di atas, maka yang menjadi model spesifik dalam penelitian ini adalah :

$$
\begin{aligned}
L i= & \operatorname{Ln}\left[\frac{P i}{1-P i}\right]=\beta_{0}+\beta_{1} \mathrm{X}_{1}+\beta_{2} \mathrm{X}_{2}+\beta_{3} \mathrm{X}_{3}+\beta_{4} \mathrm{X}_{4}+\beta_{5} \mathrm{X}_{5}+\ldots .+\epsilon \ldots \ldots \ldots \ldots . . .(2) \\
\mathrm{Y}=\beta_{0}+ & \beta_{1} \mathrm{D}_{1}+\beta_{2} \mathrm{D}_{2}+\beta_{3} \mathrm{D}_{3}+\beta_{4} \mathrm{D}_{4}+\beta_{5} \mathrm{X}_{1}+\beta_{6} \mathrm{X}_{2}+\beta_{7} \mathrm{X}_{3}+\beta_{8} \mathrm{X}_{4}+\beta_{9} \mathrm{X}_{5}+\beta_{10} \mathrm{D}_{5} \\
& +\beta_{11} \mathrm{D}_{6}+\epsilon
\end{aligned}
$$

Dimana: $Y=1$ peluang rumahtangga tetap miskin, $Y=2$ peluang rumahtangga naik dari miskin, $Y=3$ peluang rumahtangga turun dari kurang sejahtera, $Y=4$ peluang rumahtangga tetap kurang sejahtera, $\mathrm{Y}=5$ peluang rumahtangga naik dari kurang sejahtera, $Y=6$ peluang rumahtangga turun dari sejahtera, $Y=7$ peluang rumahtangga tetap sejahtera, $\mathrm{Y}=8$ peluang rumahtangga naik dari sangat miskin, $\mathrm{D}_{1}=$ Dummykepala rumahtangga berpendidikan SLTP $\left(\mathrm{D}_{1}=1\right.$ kepala rumahtangga berpendidikan SLTP, $D_{1}=0$ kepala rumahtangga berpendidikan lainnya), $\mathrm{D}_{2}=$ Dummy Pendidikan SLTA $\left(\mathrm{D}_{2}=1\right.$ kepala rumahtangga berpendidikan SLTA, $\mathrm{D}_{2}=$ 
0 kepala rumahtangga berpendidikan lainnya), $\mathrm{D}_{3}=$ Dummykepala rumahtangga berpendidikan Perguruan Tinggi $\left(\mathrm{D}_{3}=1\right.$ kepala rumahtangga berpendidikan Perguruan Tinggi, $D_{3}=0$ kepala rumahtangga berpendidikan lainnya), $D_{4}=$ Dummyjenis kelaminkepala rumahtangga $\left(D_{4}=1\right.$ kepala rumahtangga berjenis kelamin laki-laki, $\mathrm{D}_{4}=0$ kepala rumahtangga berjenis kelamin perempuan), $\mathrm{D}_{5}=$ Dummykeikutsertaan dalam pelatihan $\left(\mathrm{D}_{5}=1\right.$ pernah ikut pelatihan, $\mathrm{D}_{5}=0$ tidak pernah ikut pelatihan), $\mathrm{D}_{6}=$ Dummypendampingan $\left(\mathrm{D}_{6}=1\right.$ pendampingan Intensif, pendampingan dilaksanakan lebih dari satu kali dalam sebulan, $D_{6}=0$ pendampingan tidak intensif, pendampingan dilaksanakansatu kali dalam sebulan atau kurang), $X_{1}=$ Umur kepala rumahtangga (tahun), $X_{2}=$ Jumlah anggota rumahtangga (orang), $\mathrm{X}_{3}=$ Luas kepemilikan lahan (ha), $\mathrm{X}_{4}=$ Besar iuran kelompok(rupiah/bulan), $\mathrm{X}_{5}=$ Frekuensi pertemuan kelompok (kali/bulan), $\beta_{0}=$ Intercept $/$ konstanta, $\beta_{1 . .} \beta_{11}=$ Koefesien regresi logistic, $\epsilon=$ Error/residual Uji signifikasi yang digunakan pada regresi logistik adalah uji Wald. Nilai $\operatorname{Pr}>\mathrm{ChiSq}$ merupakan pernyataan dari nilai P-value. Apabila nilai P-vlue lebih besar dari $\alpha$ ( < 0,005) maka Ho ditolak dan Ha diterima. Sehingga jika nilai P-value pada uji Wald dari suatu variabel lebih kecil dari $\alpha$, maka didapatkan bahwa variabel tersebut berpengaruh nyata didalam model pada taraf nyata $\alpha$.

Hipotesa umum pada penelitian ini adalah adanya faktor-faktor determinan yang menyebabkan perubahan tingkat kesejahteraan peserta program. Faktorfaktor determinan tersebut adalah karakteristik rumahtangga (umur kepala rumahtangga, tingkat pendidikan kepala rumahtangga, jenis kelamin kepala rumahtangga, dan jumlah anggota rumahtangga),pembayaran iuran kelompok, frekwensi mengikuti pertemuan kelompok, keikutsertaan dalam pelatihan, kepemilikan aset rumahtangga (kepemilikan lahan) dan frekuensi pendampingan.

\section{HASIL PEMBAHASAN}

Berdasarkan hasil analisis yang dilakukan terdapat enam katagori peluang tingkat kesejahteraan rumahtangga peserta Program Desa Mandiri Pangan. Katagori peluang tingkat kesejahteraan rumahtangga tersebut yaitu:peluang rumahtangga tetap miskin, peluang rumahtangga naik dari miskin, peluang rumahtangga tetap kurang sejahtera, peluang rumahtangga naik dari kurang sejahtera, peluang rumahtangga turun dari sejahtera, dan peluang rumahtangga tetap sejahtera. 
Dan secara keseluruhan dari rekapitulasi hasil analisis peluang dapat dilihat pada tabel berikut ini:

Tabel1.Rekapitulasi Hasil Analisis Faktor Determinan Tingkat Kesejahteraan RumahtanggaPeserta Program Desa Mandiri Pangan di Provinsi Riau

\begin{tabular}{|c|c|c|c|c|c|c|c|}
\hline Peubah & $\mathrm{Y}_{1}$ & Y2 & $\mathrm{Y}_{4}$ & $Y_{5}$ & $\mathrm{Y}_{6}$ & $\mathrm{Y}_{7}$ & Keterangan \\
\hline $\operatorname{Umur}\left(\mathrm{X}_{1}\right)$ & + & - & + & + & + & + & $\begin{array}{l}\text { secara konsisten } \\
+\end{array}$ \\
\hline $\begin{array}{l}\text { Jumlah Anggota } \\
\text { Rumahtangga }\left(\mathrm{X}_{2}\right)\end{array}$ & - & - & - & - & - & - & $\begin{array}{l}\text { secara keseluruhan } \\
\text { - }\end{array}$ \\
\hline Kepemilikan Lahan $\left(\mathrm{X}_{3}\right)$ & + & + & + & + & + & + & $\begin{array}{l}\text { secara keseluruhan } \\
+\end{array}$ \\
\hline $\begin{array}{l}\text { Dummy Pendidikan } \\
\text { SLTP }\left(D_{1}\right)\end{array}$ & + & + & + & + & + & + & $\begin{array}{l}\text { secara keseluruhan } \\
+\end{array}$ \\
\hline $\begin{array}{l}\text { Dummy Pendidikan } \\
\text { SLTA }\left(\mathrm{D}_{2}\right)\end{array}$ & + & + & + & + & + & + & $\begin{array}{l}\text { secara keseluruhan } \\
+\end{array}$ \\
\hline $\begin{array}{l}\text { Dummy Pendidikan } \\
\text { Perguruan Tinggi }\left(\mathrm{D}_{3}\right)\end{array}$ & + & - & + & + & - & - & Tidak konsisten \\
\hline $\begin{array}{l}\text { Dummy Jenis Kelamin } \\
\left(\mathrm{D}_{4}\right)\end{array}$ & - & - & - & - & - & - & $\begin{array}{l}\text { secara keseluruhan } \\
\text { - }\end{array}$ \\
\hline Dummy Pelatihan $\left(\mathrm{D}_{5}\right)$ & - & - & - & - & - & - & $\begin{array}{l}\text { secara keseluruhan } \\
\text { - }\end{array}$ \\
\hline $\begin{array}{l}\text { Dummy Pendampingan } \\
\left(\mathrm{D}_{6}\right)\end{array}$ & + & + & + & + & + & + & $\begin{array}{l}\text { secara keseluruhan } \\
+\end{array}$ \\
\hline $\begin{array}{l}\text { Besar Iuran Kelompok } \\
\left(\mathrm{X}_{4}\right) \text { Frekuensi }\end{array}$ & - & - & - & - & - & - & $\begin{array}{l}\text { secara keseluruhan } \\
\text { - }\end{array}$ \\
\hline $\begin{array}{l}\text { Pertemuan Kelompok } \\
\left(\mathrm{X}_{5}\right)\end{array}$ & - & + & + & - & + & + & secara konsisten + \\
\hline
\end{tabular}

Secara keseluruhan apabila dilihat dari peluang $\mathrm{Y}_{1}$ sampai dengan Y8bahwa secara keseluruhan variabel yang bernilai positif terhadap peluang peningkatan kesejahteraan rumahtangga adalah variabel kepemilikan lahan, pendampingan, dummy pendidikan SLTP dan SLTA. Hal ini dapat diartikan bahwa semakin luas lahan yang dimiliki peserta program, maka akan semakin besar peluang rumahtangga peserta program untuk naik menjadi sejahtera. Dengan kepemilikan lahan yang luas akan menambah semangat untuk bekerja sehingga kepemilikan aset rumahtangga juga akan bertambah, yang akan dapat meningkatkan pendapatan keluarga (termasuk tabungan) yang merefleksikan kemampuan akumulasi tabungan, investasi, sehingga akan berpeluang juga merubah tingkat kesejahteraan kearah yang lebih baik.

Demikian juga dengan pendampingan, dengan semakin intensif peserta mengikuti pendampingan akan menambah pemahaman dalam pelaksanaan program 
yang akan dapat memberikan masukan sehingga ada peningkatan untuk mengembangkan usaha, yang nantinya akan berdampak pada peningkatan pendapatan dan kesejahteraan rumahtangga. Sedangkan pada dummy pendidikan terdapat perbedaan peluang rumahtangga dalam peningkatan kesejahteraan. Dimana dummy Perguruan Tinggi tidak konsisten, hal ini dapat dinyatakan bahwa kepala rumahtangga dengan tingkat pendidikan lebih tinggi bukan menjadi suatu ukuran untuk berpeluang meningkatkan kehidupan rumahtangga.

Variabel yang konsisten bernilai positif yaitu umur dan frekuensi pertemuan kelompok. Dengan semakin meningkatnya umur kepala rumahtangga sampai batas umur produktif akan mempunyai kinerja dan pengalaman yang semakin baik. Merujuk pada keragaan responden diketahui usia kepala rumahtangga berada pada usia produktif yaitu usia 15 tahun sampai dengan 64 tahun sebesar 95,56 persen. Hal ini menggambarkan bahwa semakin bertambah umur seseorang dalam batas usia produktif maka curahan waktu kerja dan keahliannya dan pola pikir akan semakin membaik sehingga akan meningkatkan pendapatan rumahtangga. Sebaliknya kepala rumahtangga yang berusia lanjut (telah berumur 64 tahun ke atas) cenderung berhenti bekerja atau memasuki umur pensiun yang akan mengakibatkan pendapatan rumahtangganya semakin menurun sehingga akan berdampak terhadap tingkat kesejahteraan rumahtangga peserta program. Sedangkan pertemuan kelompok juga konsisten bernilai positif, yang mana pertemuan kelompok ini sangat penting untuk tempat bertukar pengalaman dan pemahaman dalam berusaha, yang nantinya juga akan berdampak kepada tingkat kesejahteraan rumahtangga.

Variabel yang secara keseluruhannya bernilai negatif yaitu dummy jumlah anggota rumahtangga, jenis kelamin kepala rumahtangga, besarnya iuran kelompok dan dummy pelatihan. Hal ini menunjukkan bahwa semakin besar jumlah anggota rumahtangga maka semakin besar juga beban rumahtangga. Dengan semakin banyak jumlah anggota rumahtangga maka semakin besar kebutuhan pangan dan pengeluaran. Merujuk pada karakteristik rumahtangga responden, dapat dilihat bahwa jumlah anggota rumahtangga terbesar yaitu 49\% adalah rumahtangga dengan jumlah anggota sebanyak 3-4 orang, sebesar 36\% untuk rumahtangga dengan jumlah anggota lebih besar atau sama dengan 5 orang. Dengan demikian rata-rata jumlah anggota rumahtangga responden adalah 4 orang. Ukuran/jumlah 
anggota rumahtangga dapat memberikan indikasi beban rumahtangga, yaitu semakin besar jumlah anggota rumahtangga pada akhirnya akan semakin bertambah beban rumahtangga untuk memenuhi kebutuhan sehari-hari, dimana kebutuhan sehari-hari rumahtangga tidak merata untuk setiap anggota rumahtangga.

Variabel jenis kelamin kepala rumahtangga secara keseluruhan bernilai negatif. Apabila dilihat dari profil karaktersitik responden 88,89\% kepala rumahtangga adalah laki-laki. Seharusnya dengan kepala rumahtangga laki-laki dapat lebih memberikan curahan tenaga kerja yang lebih besar dari perempuan, yang juga akan berdampak pada peningkatan pendapatan dan kesejahteraan rumahtangga. Namun pada penelitian ini terdapat penyimpangan, kemungkinan hal ini disebabkan kepala rumahtangga tidak optimal dalam memberikan curahan tenaga kerjanya sehingga tidak berdampak dalam peningkatan kesejahteraan peserta program.

Selanjutnya dummy pelatihan juga secara keseluruhan bernilai negatif, yang mana seharusnya dengan semakin sering mengikuti pelatihan akan dapat menambah wawasan, pola pikir, pengalaman, serta inovasi baru yang dibutuhkan untuk perbaikan usaha, pekerjaan yang nantinya juga dapat meningkatkan pendapatan dan merubah tingkat kesejahteraan. Besarnya iuran kelompok juga mengindikasikan rumahtangga tersebut aktif dalam kelompok. Dari jumlah responden dapat dilihat bahwa rumahtangga peserta program termasuk yang tidak aktif dalam kelompok.

\section{KESIMPULAN DAN IMPLIKASI KEBIJAKAN}

Dari hasil penelitian, faktor-faktor determinan yang mempengaruhi tingkat kesejahteraan rumahtangga peserta Program Desa Mandiri Pangan di Provinsi Riau adalah kepemilikan lahan dan pendampingan.Kepemilikan lahan yang luas danpengusahaan secara optimal akan dapat memberikan hasil produksi yang maksimal.Hal ini akan berdampak pada peningkatan pendapatan rumahtangga dan peningkatan kesejahteraan. Demikian juga dengan pendampingan. Pendampingan tetap diperlukan karena peserta program pada umumnya masih berpendidikan rendah yang merefleksikan peningkatan sumberdaya manusia.

Disamping itu secara keseluruhan faktor-faktor lain juga memberikan peluang perubahan tingkat kesejahteraan rumahtangga peserta program seperti 
tingkat pendidikan kepala rumahtangga, umur kepala rumahtangga, dan frekuensi pertemuan kelompok.Dan sebagai implikasi kebijakan yang diperlukan dalam penguatan Program Desa Mandiri Pangan ini yaitu pemerintah tidak seharusnya menghentikan program ini. Program ini masih tetap perlu dilanjutkan, karena dari hasil penelitian dengan adanya Program Desa Mandiri Pangan dapat meningkatkan kesejahteraan rumahtangga peserta program. Secara spesifik program ini dibandingkan dengan program peningkatan kesejateraan lainnya adalah Program Desa Mandiri Pangan ini melibatkan pendampingan dalam pelaksanaannya.Pendamping sangat dibutuhkan bagi peserta program, agar lebih terarah dan tetap mendapatkan pembinaan dan bimbinganuntuk meningkatkan sumber daya manusia peserta program, yang nantinya akan berdampak positif bagi peserta program.

Apabila Program Desa Mandiri Pangan ini tetap dilanjutkan hendaknya memperhatikan program-program lintas sektoral yang ada di Kementerian Pertanian Republik Indonesia maupun di kementerian lainnya. Agar tidak terjadi overlap atau tumpang tindih dalam pelaksanaan program yang mendukung program pengentasan kemiskinan.Sehingga diharapkan nantinya program ini tepat sasaran kepada rumahtangga miskin, dan sinergiritas tiap program yang diberikan pemerintah akan memberikan hasil yang signifikan dan memuaskan, serta diperlukan juga evaluasi secara berkala disetiap program.

\section{DAFTAR PUSTAKA}

Badan Ketahanan Pangan Kementerian Pertanian. 2010. Pedoman Umum Program Aksi Desa Mandiri Pangan Menuju Gerakan Kemandirian Pangan. Badan Ketahanan Pangan Kementerian Pertanian Republik Indonesia, Jakarta.

BKKBN. 2004. Pendataan Keluarga: Selayang Pandang.http:/www.bkkbn.go. id/article_detail.php?aid=49. Diakses pada Tanggal 10 Juni 2016.

Darwis, V. 2012. Gerakan Kemandirian Pangan melalui Program Desa Mandiri Pangan: Analisis Kinerja dan Kendala. Analisis Kebijakan Pertanian 10(2): $159-179$.

Hosmer, W. David. 2013. Applied Logistic Regression 3nd Edition. John Wiley and Sons. Inc, New York.

Maddala, G.S. 1992. Introduction to Econometrics. Second Edition. Macmillan Publishing Company,New York.

Retherford, R.D. and Choe, M.K. 1992. Statistical Models for Causal Analysis. Jhon Wiley and Son Publisher, New York.

19 Faktor-Faktor Determinan Tingkat Kesejahteraan Rumahtangga Pesertap Rogram Desa Mandiri Pangan Di Provinsi Riau 
Sunarti, Euis. 2006. Indikator Keluarga Sejahtera: Sejarah Pengembangan, Evaluasi, dan Keberlanjutannya. Fakultas Ekologi Manusia Institut Pertanian Bogor, Bogor.

Wijayanti, Liony dan Ihsannudin. 2013. Strategi Peningkatan Kesejahteraan Masyarakat Nelayan Kecamatan Pademawu Kabupaten Pamekasan. Agriekonomika 2 (2): 139-152

Zuchainah, Siti. 2010. Evaluasi Program Aksi Desa Mandiri Pangan di Kabupaten Bantul. Jurnal Kebijakan dan Administrasi Publik. 15 (2) 1-16 